\title{
Estimation of Per Capita Food Consumption Patterns and Related Poverty in Kabal
}

Robina Karim ${ }^{1 *}$, Sher Khan ${ }^{1}$, Muhammad Ibrahim ${ }^{1}$ and Nasrullah ${ }^{2}$

${ }^{1}$ Department of Agricultural and Applied Economics, The University of Agriculture, AMK Campus, Mardan, Pakistan ${ }^{2}$ Department of Soil and Environmental Sciences, Cereal Crop Research Institute (CCRI), Pirsabaq Nowshera, Pakistan

\begin{abstract}
To analyze the per capita food consumption and related poverty, village Kabal a rural area of district Swat, Pakistan was selected. The average household size, based on 100 households was estimated as 6.5. It appears that on average an adult equivalent takes $372.51 \mathrm{~g}$ of flour, $74.68 \mathrm{~g}$ of meat, $70.29 \mathrm{~g}$ of rice, $177.12 \mathrm{~g}$ of vegetables, $28.31 \mathrm{~g}$ of pulses, $66.39 \mathrm{~g}$ of fruits, $166.34 \mathrm{~g}$ of milk, $53.60 \mathrm{~g}$ of fats, $6.76 \mathrm{~g}$ of black tea, and $73.21 \mathrm{~g}$ of sugar daily. Moreover, an average household spends Rs.16714.45 of their monthly income on food consumption. An individual member (adult-equivalent) of the surveyed household takes food, yielding 2857.27 calories per day. Since an adult person needs 2350 calories daily to live a normal life, this level is thus considered as the base to determine whether a person is on, above or below the poverty line. Based on average calorie intake, the surveyed households are found, on average, above poverty line $(\mathrm{PL}=1.2)$. The poverty status of the households surveyed shows that out of 100 households studied, $68.3 \%$ are above, $23.31 \%$ below, and $8.39 \%$ on the poverty line.
\end{abstract}

Keywords: Solid; Liquid; Poverty; Rural areas; Urban areas

\section{Introduction}

Food means substances, whether in liquid, concentrated, solid, frozen, dried, that are sold for ingestion or chewing by human and are consumed for their taste value. Food doesn't include alcoholic beverages, dietary supplement, soft drinks, or tobacco. Consumption is an important part of our daily life. For this purpose, people allocate their money to fulfill their food consumption desires.

The level of human food consumption and its composition are very important from a number of viewpoints. The level of food consumption determines how much a nation and its inhabitants are poor and the composition of daily food consumption determines how much different sections of population of a nation is healthy [1]. The study of a nation's food consumption patterns and analysis of changes in such patterns over some past period may also help to determine whether there have been some positive improvements in the nation's health.

Pakistan has made significant progress in increasing the per capita availability of all major food items like cereals, meat, milk, sugar, and eggs over time. Seasonal vegetables like cabbage, brinjal, ladyfinger, onion, cucumber, better guard, tomato etc. [2]. Population with high income consume more beef, mutton, poultry, and fruits. In pulses mung, masoor, beans, and g while in tea black tea and green tea and milk are the pillar of food consumption in rural and urban population of Pakistan as a result, the average per capita calorie intake increased from 2078 in 1949-50 to 2450 in 2012-13. Similar trends have been reported for protein and fats [3].

Pakistani households are found to have limited dietary diversity as only dairy products and wheat on average constitutes 40 percent of food expenditure. Instead of having a balanced diet, Pakistani households are consuming more food items which have high energy density. Households in the lowest income quintile allocate their food expenditure most towards wheat while households in the top income quintile spend greater shares of their income to buy dairy products and meat. Other important products on which average household has been spending their money are cooking oil, sugars, others and vegetables. Awareness should be spread to highlight the importance of having balanced diet to make households understand that it is more important what we eat as compare to how much we eat [4].
It has been seen that consumers in urban areas are tends to have more diversified consumption bundle than their rural counterpart. Diversified consumption bundle allows people to have better nutritional status than those whose dietary patterns are composed of only few products. In Pakistan, there is limited dietary diversity among Pakistani households [5].

The average daily calorie intake per adult equivalent has witnessed a decline during 2001-14 having its lowest value of $2135 \mathrm{Kcal}$ in 2013 14. Despite consuming more of energy dense foods calorie intake levels are still lower than the minimum subsistence level of $2350 \mathrm{Kcal}$. The calorie intake levels are seen to be higher in rural areas in contrast to urban areas while diet of urban areas are found to be more diverse. This difference varies among different social classes as well varies across different regions [4].

The current study tries to explore the four broad categories: (a) to determine the level and composition of food being consumed by an average household of the study area (b) to calculate the related monthly expenditure incurred on various food commodities (c) to determine the poverty status of the study area based on food calorie intake, and (d) to recommend policy prescriptions based on findings of the study.

\section{Materials and Methods}

This research has been conducted in village Kabal an area of district Swat. Kabal comes under the rural areas of Pakistan. A sample size of 100 households was selected, via simple random sampling technique. The data has been collected on food consumption expenditure. Lady in-charge of the household was interviewed for this purpose. For the

*Corresponding author: Karim R, Department of Agricultural and Applied Economics, The University of Agriculture, AMK Campus, Mardan, Pakistan, Tel: + 0333905290; E-mail: robikarim@yahoo.com

Received April 26, 2018; Accepted June 08, 2018; Published June 15, 2018

Citation: Karim R, Khan S, Ibrahim M, Nasrullah (2018) Estimation of Per Capita Food Consumption Patterns and Related Poverty in Kabal . Bus Eco J 9: 357. doi: 10.4172/2151-6219.1000357

Copyright: ( 2018 Karim R, et al. This is an open-access article distributed under the terms of the Creative Commons Attribution License, which permits unrestricted use, distribution, and reproduction in any medium, provided the original author and source are credited. 
collection of data, a semi-structured questionnaire (Annexure 1) was used. The questions were asked regarding household size, household structure, education status of household member, income of household and quantity, price and value of food items that were consumed by the household last week.

The collected data was analyzed employing the following techniques. Composition of actual household size along with descriptive statistics (mean, standard deviation, minimum, and maximum) was estimated and the details is presented in Table 1. Adult-equivalent household size (Table 2) was estimated, by using actual household size and weights for converting children and aged to adult-equivalent based on calorie intake requirement needed at different stages a of the age of a person (Table 3).

Data regarding food consumption items were collected on weekly basis for the entire households, which was then converted into consumption per capita per day. The actual household size (6.5) was converted into adult equivalent (6.0975). The per capita food consumption per day in $\mathrm{g}$ was estimated using the following formula.

$$
\mathrm{FCPPD}(\mathrm{gms})=\frac{\mathrm{FCPHPW}(\mathrm{kg})}{\left(6.0975^{*} 7\right)} * 1000
$$

Where

FCPPD stands for food consumption per capita per day in $\mathrm{g}$

FCPHPW represents food consumption per household per week in

\begin{tabular}{|c|c|c|c|c|c|}
\hline \multicolumn{6}{|l|}{ Descriptive Statistics } \\
\hline & $\mathbf{N}$ & Minimum & Maximum & Mean & Std. Deviation \\
\hline house hold size & 40 & 3.00 & 16.00 & 6.50 & 2.48 \\
\hline children below 5 years & 40 & 0.00 & 2.00 & 0.45 & 0.55 \\
\hline children $5-10$ years & 40 & 0.00 & 2.00 & 0.80 & 0.69 \\
\hline children $11-15$ & 40 & 0.00 & 2.00 & 1.00 & 0.82 \\
\hline adults $16-60$ & 40 & 2.00 & 11.00 & 4.05 & 1.87 \\
\hline aged above 60 & 40 & 0.00 & 4.00 & 0.25 & 0.71 \\
\hline
\end{tabular}

Table 1: Composition of household by age.

\begin{tabular}{|l|c|c|c|}
\hline & Mean & $\begin{array}{c}\text { Weight converted to } \\
\text { adult equivalent }\end{array}$ & $\begin{array}{c}\text { Adult } \\
\text { Equivalent }\end{array}$ \\
\hline Composition & & & \\
\hline children below 5 years & 0.45 & 0.55 & 0.25 \\
\hline children 5-10 years & 0.8 & 0.75 & 0.6 \\
\hline children 11-15 & 1 & 1 & 1 \\
\hline adults 16-60 & 4.05 & 1 & 4.05 \\
\hline aged above 60 & 0.25 & 0.8 & 0.2 \\
\hline house hold size & 6.5 & & 6.1 \\
\hline
\end{tabular}

Table 2: Actual household size converted to adult-equivalent

\begin{tabular}{|c|c|c|}
\hline Age (in years) & Male & Female \\
\hline $01-04$ & 1304 & 1304 \\
\hline $05-09$ & 1768 & 1768 \\
\hline $10-14$ & 2816 & 2464 \\
\hline $15-19$ & 3087 & 2322 \\
\hline $20-39$ & 2760 & 2080 \\
\hline $40-49$ & 2640 & 1976 \\
\hline $50-59$ & 2460 & 1872 \\
\hline $60+$ & 2146 & 1632 \\
\hline
\end{tabular}

Source: Adopted from CRPRID (2002). Pakistan Human Condition Report, center for Research on poverty Reduction and income Distribution, Pak Secretariat, Islamabad, p.79.

Table 3: Daily per capita calorie requirement by age and sex. kilogram and 6.0975 shows adult-equivalent and 7 represent number of a day in a week.

In the above equation multiplication by figure 1000 to convert food consumption items in to $\mathrm{g}$ from kilog (Figure 1)

The adult-equivalent per capita daily consumption of food was then converted in to calorie-intake estimates, using the calorie contents per $100 \mathrm{~g}$ of various foods (Appendix 1) (Figure 2).

We compared our study with two other studies conducted at a national level about the household integrated economic survey conducted by federal bureau of statistics Islamabad Pakistan in year 2013 for the year 2010-11 and 2011-12. The per capita per day food consumption was then converted into calorie-intake estimates, by employing calorie content in per hundred $g$ of different food items.

For estimating poverty line calories estimates were used, using the following formula:

\section{$\mathrm{PL}=\mathrm{DCI} / 2350$}

Here

PL stands for poverty line and DCI stand for daily calorie intake.

Hence a person is considering being poor if his/her power of consumption of food is 2350 calories or less than 2350 calories. If a person consumed 2350 calories daily will be on poverty line $(\mathrm{PL}=1)$, if consumed less than 2350 calories will be below the poverty line $(\mathrm{PL}<1)$, and if consumed more than 2350 calories will be above the poverty line (PL $>1)$.

\section{Results and Discussion}

\section{Household size and composition}

The result shows that the average household size of our study is 6.5 , which consist of children ( $\leq 15$ years), adults (16-60 years) and aged persons ( $\geq 60$ years) (Table 1 ).

The average household size of the respondents surveyed has been calculated as 6.5 with standard deviation as 2.48 and with a break up of 2.25 children (34.6\%), 4.05 adults (62.3\%) and 0.25 aged persons $(3.84 \%)$.

The above presented report regarding the composition of household was converted in to its adult-equivalent, based on calorie requirement necessary at different stages of the age of a person.

An adult person requires 2350 calorie per day. A child of 1-4 years of age requires 1304 calories, which estimates at 0.55 of the adult calorie requirements (2350 calorie). Similarly, the children of 5-9 years of ages' calorie requirements are estimated at 0.75 of that of adults. Children of 10-14 years may be considered equivalent to the adults. The adults up to age 59 may also be considered equivalent to an adult. For the aged people above 60 , the average calorie requirements for a male is 2146 and female is 1632, and the average of these two estimates at 1889 or 0.80 of that of adults. Hence the household members of various ages would be converted to its adult-equivalent by using the following fractions (Figure 3).

Employing the above-mentioned fraction/weights, the actual household size was converted into adult-equivalent. The actual household size of 6.5 person has now converted into 6.0975 of adultequivalent (Table 3 ).

\section{Food consumption}

The data regarding various food consumption commodities were 


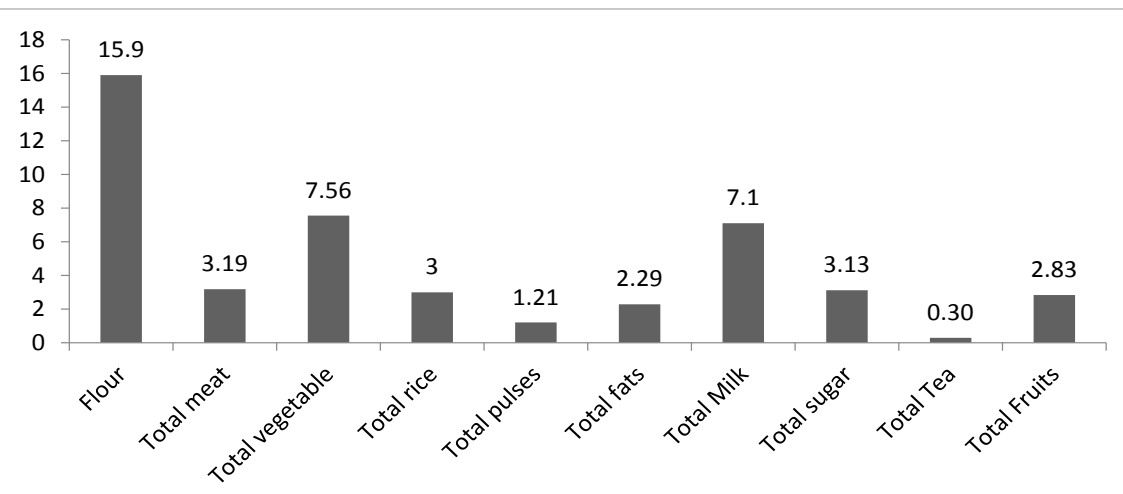

Figure 1: Food consumption per household per week $(\mathrm{Kg})$.

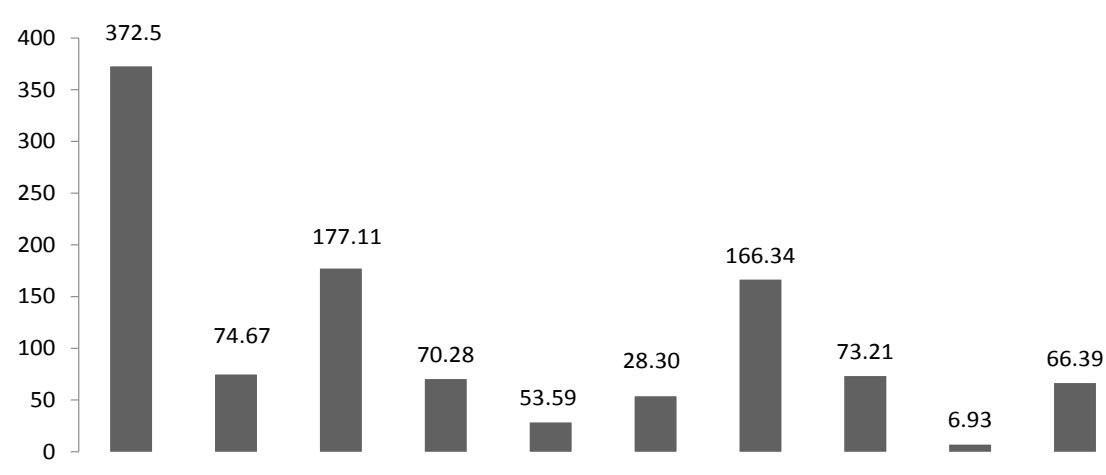

Figure 2: Food consumption per capita per day (gm).

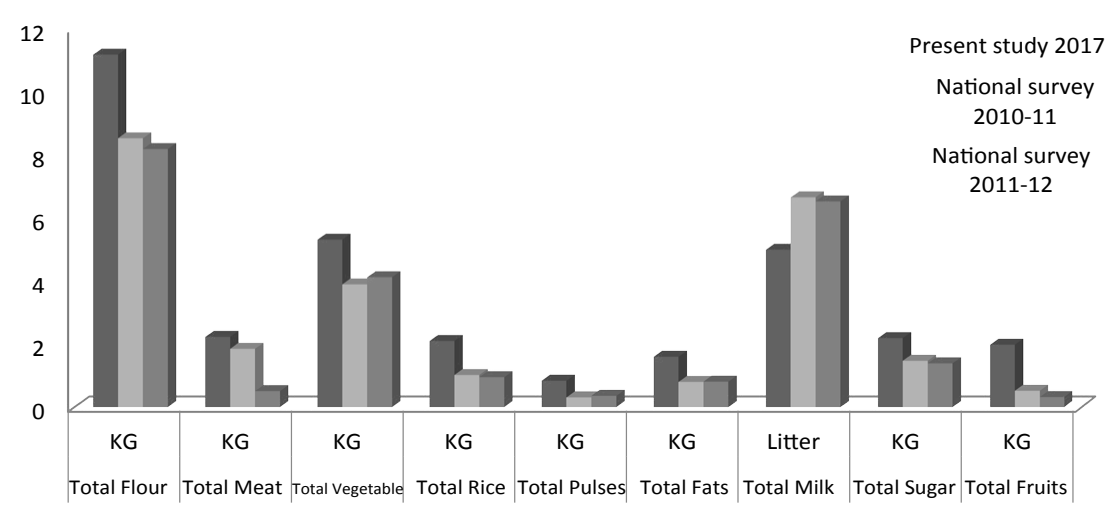

Figure 3: Comparison of present study with National survey.

collected on weekly basis, which is consumed by entire family per week, then converted into average provided in Table 4 (Figure 4).

The average household per week food consumption was then converted into per capita food consumption per day while using the following formula [6]:

$$
\operatorname{FCPPD}(\text { gms })=\frac{\mathrm{FCPHPW}(\mathrm{kg})}{\left(6.0975^{*} 7\right)} * 1000
$$

In this study household consumer's demand for following eleven food groups is considered: wheat, rice, other cereals, pulses, fresh fruits, vegetables, dairy, meats, oils, sugars and others (tea, coffee, spices and condiments etc.), Table 5 tries to summarize the daily food consumption patterns of the mentioned food groups by the surveyed households.

\section{Comparison of the current study with survey conducted at} national level

We made comparison of present estimated study with that of survey conducted at national level in Pakistan during 2010-11 and 2011-12. The details have been given in Table 6 while the graphical 
Citation: Karim R, Khan S, Ibrahim M, Nasrullah (2018) Estimation of Per Capita Food Consumption Patterns and Related Poverty in Kabal . Bus Eco J 9: 357. doi: 10.4172/2151-6219.1000357

Page 4 of 6

\begin{tabular}{|c|c|c|c|}
\hline Particulars & Consumption per Household per week (kg) & Particulars & Consumption per Household per week (kg) \\
\hline Flour & 15.1 & Mash & 0.33 \\
\hline Beef & 1.18 & Total pulses & 1.21 \\
\hline Mutton & 0.25 & Ghee & 0.88 \\
\hline Poultry & 1.76 & cooking oil & 1.41 \\
\hline Total meat & 3.19 & Total fats & 2.29 \\
\hline Okra & 0.69 & Raw milk & 5.43 \\
\hline Ginger & 0.11 & Milk Pack & 1.68 \\
\hline Garlic & 0.14 & Total Milk & 7.1 \\
\hline Potato & 0.89 & White sugar & 2.1 \\
\hline Onion & 1.05 & Gur & 1.03 \\
\hline Tomato & 2.24 & Total sugar & 3.13 \\
\hline Cucumber & 0.23 & Black Tea & 0.29 \\
\hline Squash & 0.39 & Green Tea & 0.01 \\
\hline Pumpkin & 0.33 & Total Tea & 0.3 \\
\hline Better gurad & 0.08 & Apple & 0.81 \\
\hline Pepper & 1 & Guava & 0.45 \\
\hline Brinjal & 0.36 & Mango & 0.03 \\
\hline Yam & 0.08 & Pomegranate & 0.08 \\
\hline Total vegetable & 7.56 & Peach & 0.08 \\
\hline Basmati rice & 1.83 & Banana & 0.73 \\
\hline Irri rice & 1.18 & Grapes & 0.64 \\
\hline Total rice & 3 & Pear & 0.03 \\
\hline Bean & 0.88 & Total Fruits & 2.83 \\
\hline
\end{tabular}

Table 4: Food consumption per household per week in $\mathrm{Kg}$.

\begin{tabular}{|c|c|c|c|c|c|}
\hline Particulars & $\begin{array}{c}\text { Consumption per } \\
\text { household per week per } \\
\text { kgs }\end{array}$ & $\begin{array}{l}\text { Consumption per } \\
\text { household per day in } \\
\text { gms }\end{array}$ & Particulars & $\begin{array}{l}\text { Consumption per } \\
\text { household per week } \\
\text { in kgs }\end{array}$ & $\begin{array}{l}\text { Consumption per household } \\
\text { per day in gms }\end{array}$ \\
\hline Flour & 15.9 & 372.51 & Mash & 0.33 & 7.61 \\
\hline Beef & 1.18 & 27.53 & Total pulses & 1.21 & 28.31 \\
\hline Mutton & 0.25 & 5.86 & Ghee & 0.88 & 20.5 \\
\hline Poultry & 1.76 & 41.29 & cooking oil & 1.41 & 33.09 \\
\hline Total meat & 3.19 & 74.68 & Total fats & 2.29 & 53.59 \\
\hline Okra & 0.69 & 16.11 & Raw milk & 5.43 & 127.1 \\
\hline Ginger & 0.11 & 2.55 & Milk Pack & 1.68 & 39.24 \\
\hline Garlic & 0.14 & 3.25 & Total Milk & 7.1 & 166.34 \\
\hline Potato & 0.89 & 20.79 & White sugar & 2.1 & 49.2 \\
\hline Onion & 1.05 & 24.6 & Brown sugar & 1.03 & 24.01 \\
\hline Tomato & 2.24 & 52.42 & Total sugar & 3.13 & 73.21 \\
\hline Cucumber & 0.23 & 5.27 & Black Tea & 0.29 & 6.76 \\
\hline Squash & 0.39 & 9.08 & Green Tea & 0.01 & 0.16 \\
\hline Pumpkin & 0.33 & 7.61 & Total Tea & 0.3 & 6.93 \\
\hline Better gurad & 0.08 & 1.76 & Apple & 0.81 & 19.04 \\
\hline Pepper & 1 & 23.43 & Guava & 0.45 & 10.54 \\
\hline Brinjal & 0.36 & 8.49 & Mango & 0.03 & 0.69 \\
\hline Yam & 0.08 & 1.76 & Pomegranate & 0.08 & 1.76 \\
\hline Total vegetable & 7.56 & 177.12 & Peach & 0.08 & 1.8 \\
\hline Basmati rice & 1.83 & 42.76 & Banana & 0.73 & 17.04 \\
\hline Irri rice & 1.18 & 27.53 & grapes & 0.64 & 14.94 \\
\hline Total rice & 3 & 70.29 & Pear & 0.03 & 0.59 \\
\hline Bean & 0.88 & 20.7 & Total Fruits & 2.83 & 66.39 \\
\hline
\end{tabular}

Table 5: Food consumption per capita per day in grams.

representation shows more transparent and clear picture of the comparison made.

\section{Food consumption, calorie intake and poverty}

We reproduce data on daily food consumption per capita in Table 7. The third column of the table provides estimates of calorie per 100 $\mathrm{g}$ of various food items. On the basis of these estimates, we computed estimated calorie intake in the fourth column [7].
The result given in Table 7 reveals that the daily food consumption by an average household (adult equivalent) provides him/her 2857.27 calorie, in which the flour has the greatest contribution of 1300.07 calorie, the second major contribution comes from fats that is 475.71 calorie, and thirdly the sugar that contributes 266.8 calorie. The other food as total meat, total vegetable, total rice, total pulses, total milk, total tea and total fruits contribute 145.17, 64.68, 255.83, 100.07, 176.32, 20.10, 52.54. It can also be clearly observed from Figure 4 [8]. 
Citation: Karim R, Khan S, Ibrahim M, Nasrullah (2018) Estimation of Per Capita Food Consumption Patterns and Related Poverty in Kabal . Bus Eco J 9: 357. doi: 10.4172/2151-6219.1000357

Page 5 of 6

\begin{tabular}{|c|c|c|c|c|}
\hline Particulars & Unite & Present study 2017 & National survey 2010-11 \\
\hline Total Flour & KG & 11.17 & 8.52 \\
\hline Total Meat & KG & 2.23 & 1.85 \\
\hline Total Vegetable & KG & 5.31 & 3.89 \\
\hline Total Rice & KG & 2.1 & 1.02 & 0.51 \\
\hline Total Pulses & KG & 0.84 & 0.31 & 0.8 \\
\hline Total Fats & KG & 1.6 & 6.65 & 0.36 \\
\hline Total Milk & Litter & 4.99 & 0.81 \\
\hline Total Sugar & KG & 2.19 & 1.47 \\
\hline Total Fruits & KG & 1.98 & 0.52 \\
\hline
\end{tabular}

Source: Household Size Integrated Economic Survey (HIES) May 2013 Conducted by Federal Bureau of Statistics.

Table 6: Food consumption per capita per month (FCPHPW16.9075^7)^30.

\begin{tabular}{|c|c|c|c|}
\hline Particulars & Food consumption per household per day & Calories per 100 grams of food weight & Estimated calorie per capita per day \\
\hline Flour & 372.51 & 349 & 1300.07 \\
\hline Beef & 27.53 & 212 & 58.36 \\
\hline Mutton & 5.86 & 178 & 10.43 \\
\hline Poultry & 41.29 & 185 & 76.39 \\
\hline Total meat & 74.68 & & 145.18 \\
\hline Okra & 16.11 & 31 & 4.99 \\
\hline Ginger & 2.55 & 80 & 2.04 \\
\hline Garlic & 3.25 & 149 & 4.84 \\
\hline Potato & 20.79 & 81 & 16.84 \\
\hline Onion & 24.6 & 41 & 10.09 \\
\hline Tomato & 52.42 & 20 & 10.48 \\
\hline Cucumber & 5.27 & 15 & 0.79 \\
\hline Squash & 9.08 & 23 & 2.09 \\
\hline Pumpkin & 7.61 & 26 & 1.98 \\
\hline Better gurad & 1.76 & 19 & 0.33 \\
\hline Pepper & 23.43 & 26 & 6.09 \\
\hline Brinjal & 8.49 & 24 & 2.04 \\
\hline Yam & 1.76 & 118 & 2.07 \\
\hline Total vegetable & 177.12 & & 64.68 \\
\hline Basmati rice & 42.76 & 364 & 155.64 \\
\hline Irri rice & 27.53 & 364 & 100.2 \\
\hline Total rice & 70.29 & & 255.84 \\
\hline Bean & 20.7 & 350 & 72.43 \\
\hline Mash & 7.61 & 363 & 27.64 \\
\hline Total pulses & 28.31 & & 100.07 \\
\hline Ghee & 20.5 & 900 & 184.5 \\
\hline Cooking oil & 33.09 & 880 & 291.22 \\
\hline Total fats & 53.59 & & 475.72 \\
\hline Raw milk & 127.1 & 106 & 134.73 \\
\hline Milk Pack & 39.24 & 106 & 41.6 \\
\hline Total Milk & 166.34 & & 176.32 \\
\hline White sugar & 49.2 & 391 & 192.37 \\
\hline Brown sugar & 24.01 & 310 & 74.44 \\
\hline Total sugar & 73.21 & & 266.82 \\
\hline Black Tea & 6.76 & 290 & 19.62 \\
\hline Green Tea & 0.16 & 300 & 0.48 \\
\hline Total Tea & 6.93 & & 20.1 \\
\hline Apple & 19.04 & 58 & 11.04 \\
\hline Guava & 10.54 & 78 & 8.22 \\
\hline Mango & 0.69 & 64 & 0.44 \\
\hline Pomegranate & 1.76 & 68 & 1.19 \\
\hline Peach & 1.8 & 53 & 0.96 \\
\hline Banana & 17.04 & 108 & 18.4 \\
\hline Grapes & 14.94 & 80 & 11.95 \\
\hline Pear & 0.59 & 58 & 0.34 \\
\hline Total Fruits & 66.39 & & 52.55 \\
\hline Total & & & 2857.27 \\
\hline
\end{tabular}

Table 7: Estimated calorie per capita per day. 


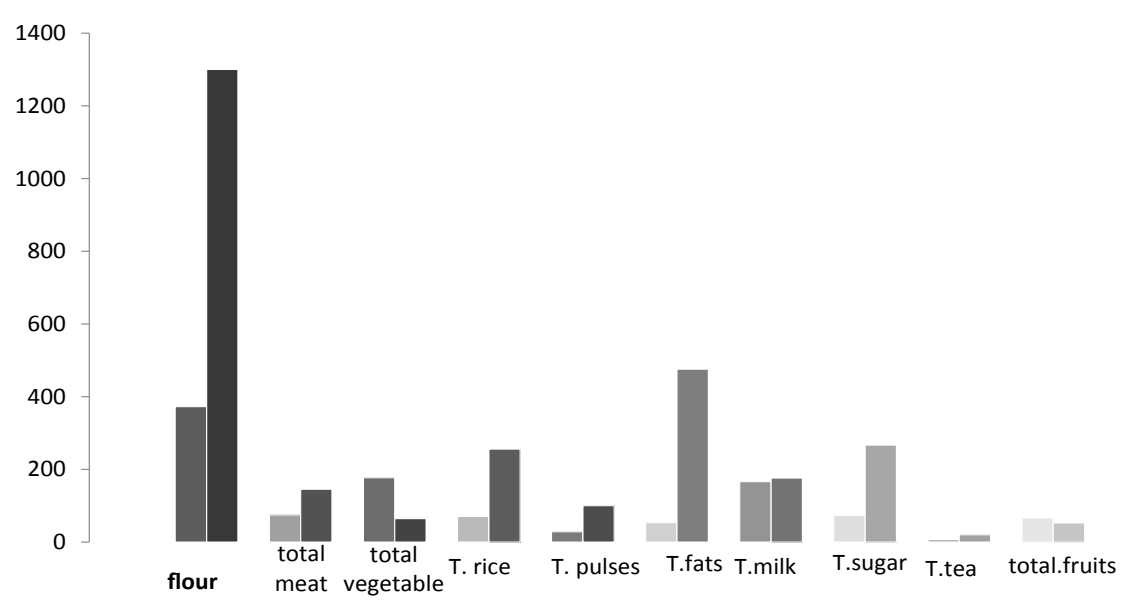

Figure 4: Per capita food consumption and their estimated calories.

\section{Calorie intake and poverty line}

Since an adult person required 2350 calorie to live a normal life, this standard is used to determine whether a person is on, above or below the poverty line. For this purpose we used the following formula.

\section{$\mathrm{PL}=\mathrm{DCI} / 2350$} intake.

Here PL stands for poverty line and DCI stand for daily calorie

If $\mathrm{PL}>1$, it shows the person is above poverty line; if $\mathrm{PL}=1$, its mean that the person is on the poverty line and if $\mathrm{PL}<1$, then we say that the person is below the poverty line. Using the above formula we compute the poverty line for the average calorie intake estimated.

$\mathrm{PL}=2857.27 / 2350=1.2$. This indicate that respondent of our survey is little above the poverty line. If each of these households are taken as individual case then out of 100 households studied, $68.3 \%$ of households are above, $23.31 \%$ below, and $8.39 \%$ fall on the poverty line [9].

\section{Conclusion}

In the light of the analyses carried out and the results derived, some of the important points may be summarized as: the average household size, based on 100 sample size, is 6.5 consist of 2.25 children (34.6\%), 4.05 adults $(62.3 \%)$ and 0.25 aged people (3.84\%). An adult-equivalent household size was estimated as 6.0975 consuming $372.5 \mathrm{~g}$ of flour, $74.6 \mathrm{~g}$ of meat, $177.1 \mathrm{~g}$ of vegetables, $70.2 \mathrm{~g}$ of rice, $28.3 \mathrm{~g}$ of pulses, $53.5 \mathrm{~g}$ of fats, $166.3 \mathrm{~g}$ of milk, $73.2 \mathrm{~g}$ of sugar, $6.92 \mathrm{~g}$ of tea and $66.3 \mathrm{~g}$ of fruits daily. Comparing the current study with survey carried out at national level, flour, vegetable and fruits consumption per capita per month is prominently more in present study while the pulses, fats and sugar and rice consumption is approximately equal in all study, meat and milk consumption of present study is less than national survey. In the study area an adult-equivalent takes 2857.27 calorie from daily food consumption estimating the resultant poverty line as 1.2. Based on poverty status analysis $68.3 \%$ households are above poverty line, $23.31 \%$ below poverty line, and $8.39 \%$ fall on the poverty line.
On the basis of the conclusion drawn, it is recommended that a similar study should be replicated to further reinvestigate the research findings with larger sample size as well as data collection techniques should be improved. The comparison with national survey shows that in most of the cases, food consumption has reduced due to price hike, so it is suggested that actions should be taken to either stabilize the prices by subsidizing the major food items or to increase the monthly incomes of households to help them increase food consumption. Almost thirty percent of the population under study is suffering from poverty, so policy makers and other involved should take a serious note of it and should apply some strategies to make the population better off.

\section{References}

1. Chan RSM, Woo J (2010) How Effective is the Current Public Health Approach Int J Environ Res Public Health 7: 765-783.

2. Malik SJH, Nazli A, Shahzad A, Mehmood A (2015). Food Consumption Patterns and Nutrition; International Food Policy Institute (IFPRI) and Pakistan Strategy Support Program USAID.

3. GoP (2017) Economic Survey of Pakistan 2016-17, Government of Pakistan, Islamabad.

4. Haider A, Zaidi M (2017) Food Consumption Patterns and Nutrition Disparity in Pakistan, MPRA: Paper No. 83522.

5. Malik SJ, Nazli H, Whitney E (2014) Food Consumption Patterns and Implications for Poverty Reduction in Pakistan. The Pakistan Development Review 54: 651-670.

6. Karim R (2006) An investigation into food consumption patterns in rura Peshawar, Master thesis submitted to the Department of Agricultural Economics, NWFP Agricultural University, Peshawar, Pakistan.

7. CRPRID (2002) Pakistan Human Condition Report, Center for Research on Poverty Reduction and Income Distribution, Pak Secretariat: Islamabad, 79.

8. HIES (2013) Household Size Integrated Economic Survey, Federal Bureau of Statistics: Islamabad, Pakistan.

9. Tajammal H (1985) Food consumption table for Pakistan, Department of Agricultural Chemistry and Human Nutrition, N-W-F-P Agricultural University Peshawar. 